\title{
Kader Aisyiah Siaga Cegah Hipertensi
}

\author{
AGUS WIDIYATMOKO1 \\ 1. Pendidikan Dokter, Fakultas Kedokteran dan Ilmu Kesehatan UMY, Yogyakarta \\ Jl. Brawijaya, Kasihan, Bantul Yogyakarta, 55183 Telp: +62 274387656 (hunting) \\ Email:aguswidi@umy.ac.id \\ DOI: 10.18196/ppm.32.204
}

\begin{abstract}
Abstrak
World Health Organization (WHO) memperkirakan jumlah penderita hipertensi, jantung, dan pembuluh darah di dunia akan meningkat hingga tiga kali lipat pada tahun 2025 yang mencapai 9,4 juta orang. Hipertensi memiliki komplikasi yang banyak dan dapat menyebabkan kecacatan serta kematian. Penyakit hipertensi dapat dicegah dengan pola hidup yang sehat. Masyarakat perlu diberikan edukasi terus- menerus untuk memiliki pola hidup yang baik sehingga terhindar dari penyakit hipertensi .Organisasi masyarakat Aisyiah memiliki potensi untuk aktif melakukan promosi dan prevensi hipertensi, jantung, dan pembuluh darah di masyarakat. Program "Kader Aisyiah Siaga Cegah Hipertensi" ini bertujuan untuk meningkatkan pengetahuan dan keterampilan pengurus Aisyiah dalam melakukan promosi pola hidup sehat dan mencegah hipertensi.Metode kegiatan pengabdian kepada masyarakat ini adalah pelatihan yang terdiri dari ceramah, diskusi dua arah, dan dilanjutkan dengan penugasan di lapangan. Peserta adalah empat puluh pengurus Aisyiah di wilayah Tamantirto, Kasihan, Bantul sebagai wilayah yang paling dekat dengan kampus UMY. Kegiatan dilaksanakan secara berkelompok, terdiri atas 2 sesi dan 2 materi. Kegiatan melibatkan tim pengabdian sebagai narasumber, anggota, dan pengurus Aisyiah dengan menggunakan modul yang dibuat oleh tim pengabdian. Mitra kegiatan adalah organisasi masyarakat Aisyiah di Desa Tamantirto, Kasihan, Bantul.
\end{abstract}

Kata Kunci: Pelatihan, Hipertensi, Aisyiah

\section{Pendahuluan}

Hipertensi merupakan masalah kesehatan global yang berakibat meningkatkan angka kesakitan, kematian, serta beban biaya Kesehatan, termasuk di Indonesia. Hipertensi merupakan faktor risiko terhadap kerusakan organ penting seperti otak, jantung, ginjal, retina, pembuluh darah besar (aorta) dan pembuluh darah perifer. Riset Kesehatan Dasar (Riskesdas) tahun 2018 menunjukkan peningkatan prevalensi hipertensi di Indonesia dengan jumlah penduduk sekitar 260 juta, yakni 34,1\% dibandingkan 27,8\% pada Riskesdas tahun 2013 (Riset Kesehatan Dasar Kementerian Kesehatan RI, 2018). Dalam upaya menurunkan prevalensi dan insiden penyakit kardiovaskular akibat hipertensi, dibutuhkan tekad kuat dan komitmen bersama secara berkesinambungan dari semua pihak terkait tenaga kesehatan, pemangku kebijakan, dan peran serta masyarakat.

Penanggulangan masalah hipertensi di Indonesia meliputi upaya promotif, preventif, kuratif, dan rehabilitatif yang dilaksanakan berdasarkan pedoman berbasis bukti (Evidence Based Medicine). Penanganan hipertensi di negara-negara Asia sangat penting karena prevalensi hipertensi terus meningkat, termasuk di Indonesia. Di sebagian besar negara Asia Timur, penyakit kardiovaskular sebagai komplikasi hipertensi terus meningkat. (Soenarta et.al., 2015). Karakteristik spesifik untuk populasi Asia yang berbeda dengan ras lain di dunia adalah kejadian stroke, terutama stroke hemoragik, dan gagal jantung noniskemik lebih sering ditemukan sebagai luaran dari hipertensi terkait penyakit kadiovaskular. (Kario et.al., 2018). Selain itu, hubungan antara tekanan darah dan penyakit kardiovaskular lebih kuat di Asia dibandingkan negara barat. Populasi Asia terbukti memiliki karakteristik sensitivitas terhadap garam yang lebih tinggi (higher salt sensitivity), bahkan dengan obesitas ringan dan asupan garam yang lebih banyak. (Grillo et.al., 2019).

\section{Metode Pelaksanaan}

Program ini menawarkan solusi untuk meningkatkan pengetahuan dan keterampilan anggota dan pengurus Aisyiah dalam berperan aktif terhadap pencegahan hipertensi di 
wilayahnya. Program ini juga akan membekali anggota dan pengurus Aisyiah untuk melakukan edukasi hipertensi kepada masyarakat luas. Solusi dapat dirinci sesuai dengan setiap permasalahan sebagai berikut:

1. Kurangnya pengetahuan pengurus Aisyiah tentang hipertensi secara lengkap yang diperlukan dalam edukasi di masyarakat. Solusi yang ditawarkan adalah penyusunan dan penyediaan modul bagi anggota dan pengurus Aisyiah yang berisi materi tentang:

a) Penapisan dan deteksi hipertensi,

b) Konfirmasi diagnosis hipertensi,

c) Penilaian risiko penyakit kardiovaskuler,

d) Penatalaksanaan hipertensi

2. Kurangnya peran aktif pengurus Aisyiah dalam kegiatan edukasi masyarakat tentang hipertensi. Solusi yang ditawarkan adalah pelatihan modul yang telah disusun. Dengan pelatihan diharapkan para anggota dan pengurus Aisyiah siap untuk melakukan edukasi kepada masyarakat.

3. Kurangnya pengetahuan masyarakat tentang hipertensi. Solusi yang ditawarkan adalah melakukan edukasi kepada masyarakat. Kegiatan ini dilakukan oleh anggota dan pengurus Aisyiah yang telah mengikuti pelatihan dalam program PKM ini.

Metode kegiatan dalam pengabdian ini adalah pelatihan dan praktik. Kegiatan yang dilaksanakan dalam pelatihan adalah ceramah online (materi dari narasumber), diskusi dua arah dengan grup media sosial, dan praktik pengukuran tekanan darah.

Peserta kegiatan adalah anggota dan pengurus Aisyiah ranting Tamantirto sebanyak empat puluh orang dengan kriteria :

1. Anggota dan pengurus Aisyiah

2. Bersedia ikut dalam pelaksanaan keseluruhan kegiatan

3. Bertempat tinggal di wilayah Tamantirto

\section{Hasil dan Pembahasan}

Telah dilaksanakan pembuatan media penyuluhan berupa buku saku hipertensi untuk kader Aisyiah, materi video penyuluhan yang terdiri atas materi 1 tentang pengertian hipertensi dan materi 2 tentang tatalaksana hipertensi. Materi video penyuluhan telah di-upload di youtube dan dibagikan secara offline kepada kader. Karakteristik peserta pengabdian dari pengurus dan anggota Ranting Aisyiah Tamantirto tampak pada tabel 1.

Dari tabel ini, dapat diketahui bahwa peserta berusia antara $45-71$ tahun. Usia peserta yang di atas 40 tahun memiliki risiko untuk terjadinya hipertensi. (Gates et.al., 2004). Dari data Riskesdas 2018 didapatkan penderita hipertensi terjadi pada kelompok umur 31-44 tahun (31,6\%), umur 45-54 tahun (45,3\%), umur 55-64 tahun (55,2\%). (Riskesdas Kemenkes RI, 2018). Hal ini memungkinkan peserta bisa mendapatkan pengetahuan untuk mencegah hipertensi bagi diri sendiri, selain untuk orang lain. Pelatihan ini lebih mudah diberikan karena tingkat pendidikan peserta $83,3 \%$ adalah sarjana.

Kondisi pandemi Covid-19 ini membuat pemberian materi secara langsung dengan tatap muka kepada kader menjadi terkendala. Untuk melakukan transfer of knowledge tentang hipertensi telah dibuat grup whatsapps (WAG) antara pemateri dengan kader Aisyiah ranting Tamantirto. Terdapat tiga puluh anggota dari kader Aisyah. Sebelum dilakukan tanya jawab, dilakukan pretest terlebih dahulu untuk para kader. Hasil diskusi lewat grup whatsapp ini cukup memberikan tambahan pengetahuan bagi para kader. Hal ini dapat dilihat dari hasil posttest yang meningkat $129,2 \%$ dari pretest. Dalam diskusi ini juga dipaparkan tentang patogenesis hipertensi yang dapat disebabkan oleh beberapa faktor. Faktor yang penting adalah diet tinggi 
natrium. Natrium merupakan sumber nutrisi yang banyak dijumpai pada makanan sehari-hari seperti garam, bumbu penyedap, dan bahan pengawet. (Büssemaker et.al., 2010). Selain itu, dari diskusi ini. juga diluruskan beberapa pengertian yang masih belum tepat untuk penanganan hipertensi. Pengertian masyarakat tentang waktu harus dilakukan terapi dan durasi/lamanya terapi pada penderita hipertensi juga dibahas dalam diskusi ini. Terapi untuk hipertensi ini penting untuk disampaikan karena dari data Riskesdas 2018 didapatkan data bahwa hanya 8,8\% penderita hipertensi yang berobat. (Riskesdas Kementerian RI, 2018).

Tabel 1.

Karakteristik Peserta

\begin{tabular}{llc}
\hline Karakteristik & Frekuensi (n) & Persentase (\%) \\
\hline Jenis Kelamin & 30 & \\
Perempuan & 30 & \\
\hline Usia & & \\
$45-71$ Tahun & 30 & \\
\hline Status Pernikahan & & \\
Menikah & & $41 \%$ \\
\hline Pendidikan & 5 & $93 \%$ \\
SD & 25 & \\
SMP & & \\
SMA & & \\
Sarjana/ Diploma & & \\
\hline Pre Test & & \\
Post Test & &
\end{tabular}

Gambar 1.

Screenshoot Whatsapps Group Aisyiah Cegah Hipertensi

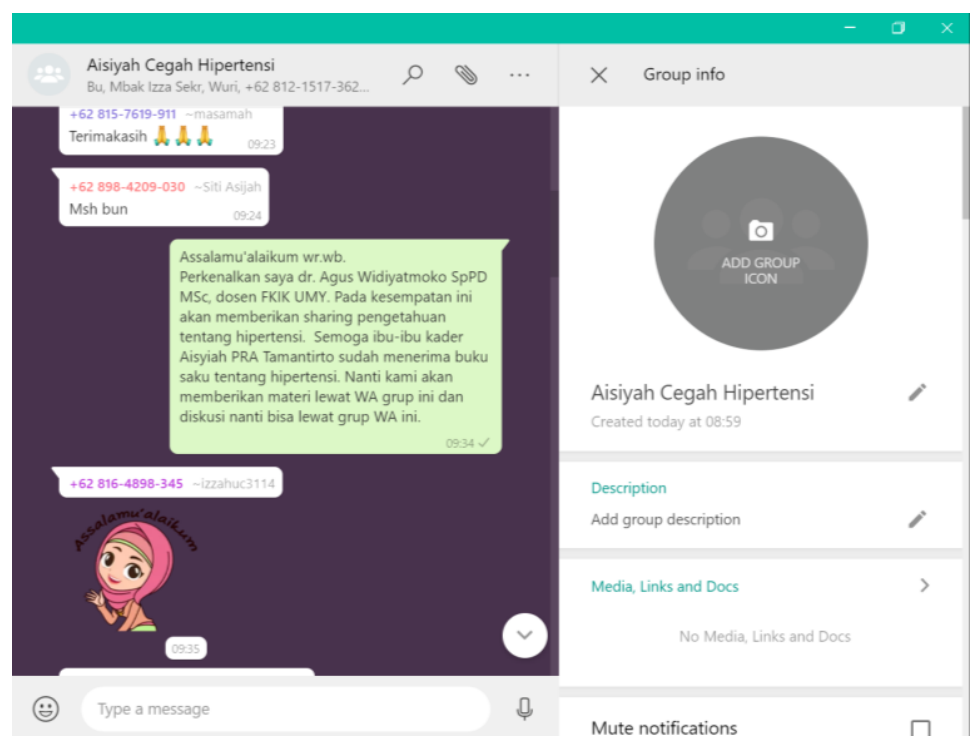


Materi yang diberikan lewat link youtube:

https://www.youtube.com/watch?v=58nAt2cmdG8

https://www.youtube.com/watch?v=rHmo0NZ6jD0

Gambar 2.

Screenshoot Materi Youtube

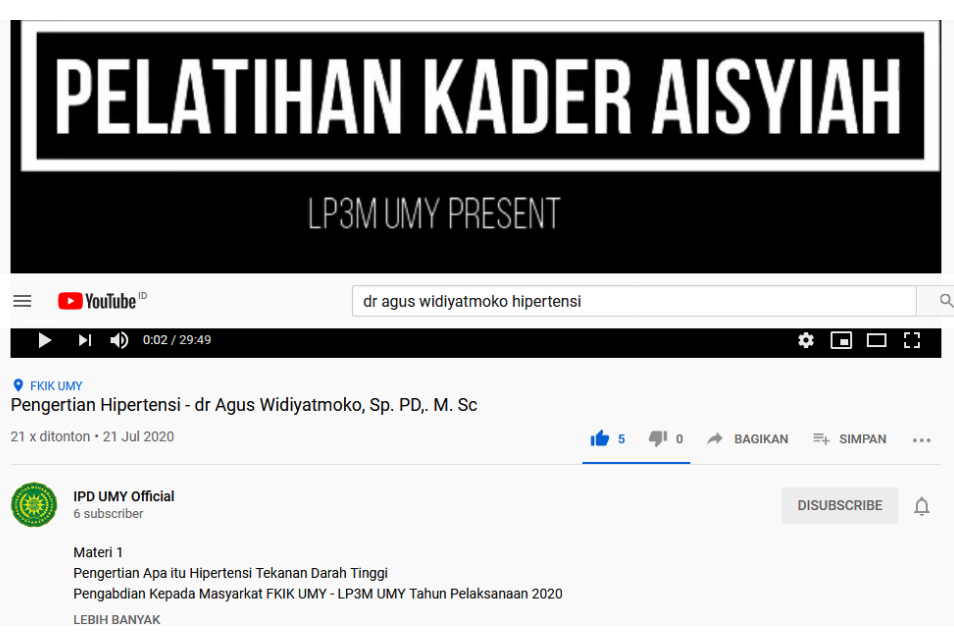

Materi yang diberikan lewat youtube meliputi kriteria hipertensi di Indonesia, cara mengukur tekanan darah yang benar, diet yang baik, dan tatalaksana yang baik pada hipertensi untuk mencegah terjadinya komplikasi. Kriteria hipertensi menggunakan kriteria yang dipakai oleh Perhimpunan Dokter Spesialis Kardiovaskular Indonesia (PERKI) tahun 2015. (Soenarto et.al., 2015).

Gambar 3.

Buku Saku Hipertensi

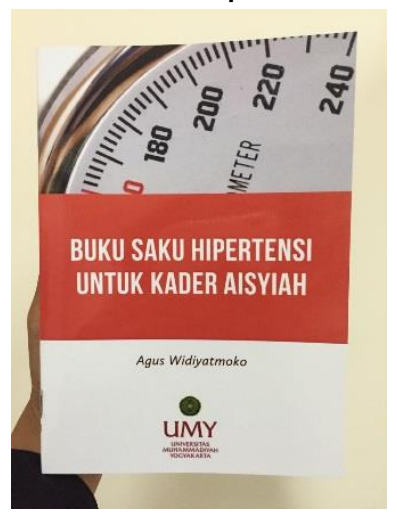

Materi yang diberikan lewat buku adalah pengetahuan praktis hipertensi yang merupakan bahan dari pembuatan konten di youtube. Dengan demikian, diharapkan kader bisa membaca buku saku dan diperjelas dengan melihat konten di youtube.

Kader juga diberikan bantuan satu buah alat pengukur tekanan darah otomatis merek Omron. Diharapkan kader bisa berlatih menggunakan alat tersebut. Tindak lanjut dari pemberian alat ini adalah kader mampu melakukan pengukuran tekanan darah secara mandiri. 


\section{Simpulan}

Didapatkan peningkatan kesadaran kader Aisyiah tentang penyakit hipertensi yang bisa mengakibatkan komplikasi pada berbagai organ tubuh. Peserta pengabdian juga memiliki tambahan pengetahuan tentang berbagai cara pencegahan penyakit hipertensi dan pencegahan untuk terjadinya komplikasi hipertensi.

\section{Ucapan Terima Kasih}

1. LP3M UMY yang telah membiayai kegiatan pengabdian masyarakat dengan judul "Kader Aisyiah Cegah Hipertensi"

2. Segenap pengurus Ranting Aisyiah Tamantirto yang dengan antusias mengikuti kegiatan ini walaupun dalam kondisi pandemi Covid-19

3. Dekan dan segenap wakil dekan FKIK UMY yang telah memberi kesempatan untuk melakukan kegiatan pengabdian ini.

\section{Daftar Pustaka}

A Grillo, L Salvi, P Coruzzi, P Salvi, G Parati (2019). Sodium Intake and Hypertension. Nutrients,

E Büssemaker, U Hillebrand, M Hausber (2010). Pathogenesis of Hypertension: Interactions Among Sodium, Potassium, and Aldosterone. American Journal of Kidney Disease

K Kario, CH Chen, S Park, CG Park, S Hoshide (2018). Consensus Document on Improving Hypertension Management in Asian Patients, Taking Into Account Asian Characteristics. Am Heart Assoc

PE Gates, H Tanaka, WR Hiatt, DR Seals (2004). Dietary Sodium Restriction Rapidly Improves Large Elastic Artery Compliance in Older Adults With Systolic Hypertension. Hypertension. Am Heart Assoc

Riset Kesehatan Dasar (2018). Kementerian Kesehatan RI

Soenarta AA dkk (2015). Pedoman Tatalaksana Hipertensi pada Penyakit Kardiovaskuler. PERKI 